\title{
The appreciation of the traditional knowledge of fire management as a tool for conflict management and strengthening of social participation in the Serra da Canastra National Park
}

\author{
Bianca Thais Zorzi Tizianel ${ }^{*}$, Fernando Augusto Tambelini Tizianel ${ }^{1}$, Luiz Francisco Ditzel \\ Faraco $^{2}$ e Lilian de Carvalho Lindoso ${ }^{3}$
}

\footnotetext{
${ }^{1}$ Serra da Canastra National Park - Instituto Chico Mendes de Conservação da Biodiversidade (ICMBio);

${ }^{2}$ ICMBio Curitiba - Instituto Chico Mendes de Conservação da Biodiversidade (ICMBio);

${ }^{3}$ Serra da Ibiapaba Protected Area- ICMBio;

*E-mail para contato: bianca.tizianel@icmbio.gov.br
}

\begin{abstract}
The fire, which is a socioenvironmental conflict factor in the Serra da Canastra National Park, was used, as an intervention proposal, as a theme for the approaching of conflicting actors. A meeting was held with residents of the Vão dos Cândidos community. A historical rescue was carried out, with knowledge accumulated over 200 years of management, and participatory planning of controlled burnings and firebreak by 2018. The approach did not aim to locating responsible for fires and information about the use of fire was sought. From the guiding questions "How," "For what?" And "When," they reported the use of fire in the region. The participation of neighbors in the burn was emphasized, which leads to the reinforcement of community ties. Residents reported that after the fire ban a conflict with the environmental agencies has started and that they considered fire fines unfair, since there is no interest from the residents in fires hitting their properties. The demand of fire use in August (peak of the drought period - late fire) after short rainfall period, which will ensure pasture regrowth during the end of the dry season (September) was highlighted. This information impacted the planning of the Protected Area (PA), which covered only the reversal of late fire for early and modal fire, and by that it should also predict a minimum area for late fire in order to meet the properties management. A intended future scenario was defined - what would need to be agreed upon for the community to be able to use fire, with authorization and planning, where the following subjects were highlighted: being able to put out fires without risk of being charged; use of fire according to legal norms and meeting agreements; prior communication to neighbors and ICMBio; protection of legal reserves and forest formations; choice of area being the owner's responsibility. A spoken map was produced with the location of the burning areas, where each interested party indicated the desired area. From this information a Community controlled burn authorization was issued. The proposal allowed to establish a minimum relationship of trust between both sides and to promote appreciation of the knowledge of traditional fire management. This is essential for restoring the use of fire and creating a sense of belonging regarding fire management at PA.
\end{abstract}

Keywords: controlled burn, community, fire management. 